\title{
COMPUTER-SUPPORTED COLLABORATIVE KNOWLEDGE BUILDING USING A SUSTAINABILITY ASSESSMENT FRAMEWORK AND MICROSOFT TEAMS
}

\author{
Ralph Buchal \\ Western University \\ rbuchal@uwo.ca
}

\begin{abstract}
Ashby's sustainability assessment method provides a systematic framework for dealing with complex, multidisciplinary problems. It explicitly addresses many desired graduate attributes, and is an excellent framework to provide scaffolding for computer-supported collaborative knowledge building. This paper describes experience using Ashby's method in conjunction with the Microsoft Teams collaboration platform in a third-year group sustainability assessment project. Students found Teams to be effective and easy to use, and the resulting group reports demonstrated development and application of most CEAB graduate attributes, particularly professionalism, impact on society and the environment, and life-long learning.
\end{abstract}

Keywords: Sustainability, graduate attributes collaborative knowledge building, computer supported collaborative learning, Microsoft Teams

\section{INTRODUCTION}

A well-rounded engineer must develop competence in several areas beyond mastery of technical knowledge. This has been recognized by the Canadian Engineering Accreditation Board (CEAB) [1], and Canadian engineering schools are responding by adapting their curricula and learning activities to develop these attributes. Among these attributes, some are addressed in only a few courses. These include Professionalism, Impact of Engineering on Society and the Environment, and LifeLong Learning.

These CEAB attributes reflect the view that engineers need to be more broadly educated to effectively contribute solutions to pressing problems facing society. Many of these problems are "wicked problems" [2] requiring an interdisciplinary and collaborative approach.

\section{COLLABORATIVE KNOWLEDGE BUILDING}

Collaborative approaches to learning are widely accepted by educational researchers and practitioners to be the most effective modes of learning [3], [4], [5], [6]. Stahl has proposed a collaborative knowledge building model (Figure 1) that explicitly identifies key activities including: articulating personal perspectives and viewpoints; comparing and integrating multiple perspectives; identifying and reconciling contradictions; filling gaps; clarifying and negotiating meanings; linking new knowledge into existing personal and group knowledge structures; modifying beliefs; and reflecting on learning [5], [7], [8].

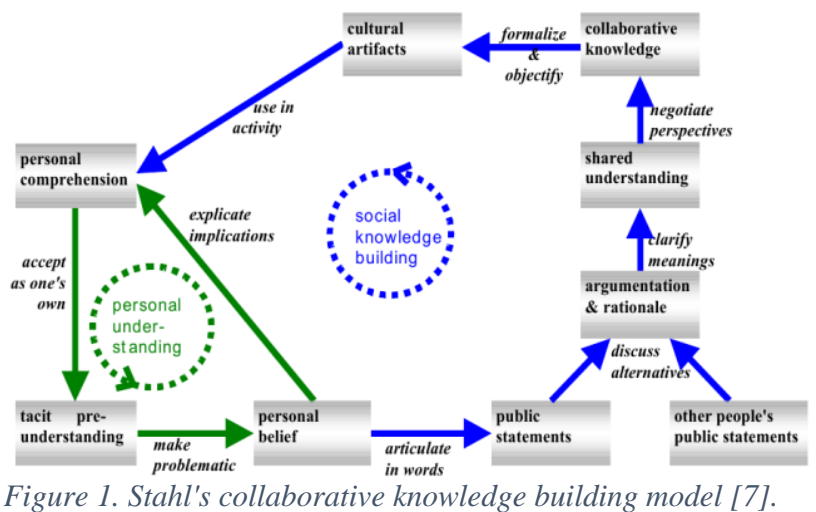

Only a few researchers have analyzed the adequacy of existing collaboration tools (e.g. [7]), and many available tools lack affordances to effectively support rich collaborative activities. Also, most studies observe how students use collaboration tools naturally, without any intervention or guidance. It is clear that students do not engage in rich collaborative behaviours naturally, and many researchers now agree that intentional training and on going support from instructors are key ingredients for rich and successful collaboration among students [3], and that supports in the form of scripts, training and guidance can be effective in developing collaborative practices [9].

\section{IDENTIFICATION AND EVALUATION OF COLLABORATION TOOLS}

The author has reviewed and evaluated available collaboration tools, based on the affordances required to 
support rich collaborative activities as described by Stahl and others. No integrated tool was found that meets all of the requirements, but among available tools Microsoft SharePoint was found to be one of the most capable. The author has many years of experience with SharePoint [10]. A recent study using SharePoint as a platform for collaborative knowledge building showed that students found it easy to use and useful for supporting collaborative projects, but that it still has a number of shortcomings [11]. Microsoft has recently introduced the Teams collaboration app as part of Office 365. Teams extends the functionality of Microsoft SharePoint, with a simplified user interface and the addition of a group chat capability. It is available as an app for iOS and Android devices, as well as running in a browser or app on a Windows or Mac computer. It is part of Office 365, and is included in the educational license of Office 365 available at many universities.

\section{SUSTAINABILITY ASSESSMENT METHOD}

The sustainability assessment method developed by Ashby et al. [12], [13] provides a systematic framework for dealing with complex, multidisciplinary problems, and promotes a systems-thinking approach (Figure 2). It is also an excellent framework to provide scaffolding for collaborative knowledge building. The method is used to assess the sustainability of a proposed solution. The method consists of five stages: problem definition, stakeholder analysis, fact-finding, synthesis and evaluation, and reflection. The problem definition stage defines the objectives, scope and time scale of a proposed solution to be assessed. Stakeholder analysis identifies the stakeholders and their concerns. The fact-finding stage gathers factual information in several categories: materials, energy, environment, legislation and regulations, economics and society. This ensures that all perspectives are considered. The synthesis and evaluation stage uses the facts along with argumentation, judgement and reasoning to assess the positive and negative impacts on environmental, economic and social sustainability. The reflection stage reflects on the positive and negative impacts and reaches conclusions about whether the objective is achievable, and whether the benefits outweigh the negative impacts. Reflection also suggests new or different ways to achieve the objective.

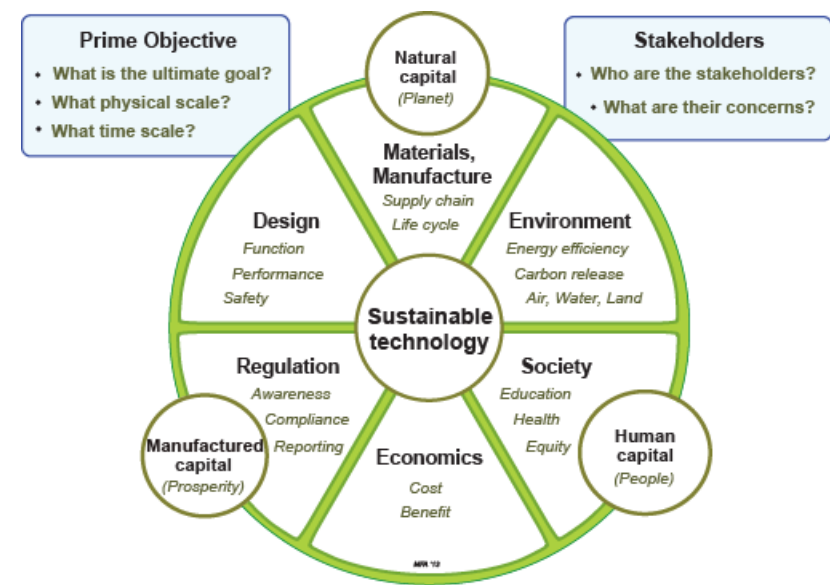

Figure 2. Ashby's Sustainability Assessment Framework [12].

Ashby's method is intended to be used in conjunction with the CES Edupack material selection software [14]. CES Edupack includes searchable databases of nations of the world, legislation and regulations, energy storage systems, low carbon power systems, and nuclear energy systems. The nations of the world database includes a variety of information about every nation in the world. The information is grouped into several categories: demographic information, education, human rights and governance, economy and development, health, energy, carbon and environment, and military expenditures. The low carbon power database contains a description, resource intensity, operational parameters, and status of most if not all power generation technologies. These technologies include: conventional fossil fuels, fuel cells, geothermal, hydro, nuclear, biomass, solar, wind, wave, and tidal.

The sustainability assessment method is very effective in evaluating the feasibility of a proposed solution or articulation, but it does not help in generating alternative solutions based on a problem or need. Ashby and his colleagues show several worked examples of the assessment of particular solutions, but he does not extend this to a comparison and ranking of multiple alternatives. However, this extension is straightforward.

In the domain of sustainability, there are many known articulations or solutions, and each can be assessed using this method. A comparison of alternatives would involve the comparative assessment of several candidates. For example, the method could be used to assess wind energy and solar energy as two alternative solutions, and the results could be compared.

\section{DESCRIPTION OF COURSE PROJECT}

A sustainability assessment project was introduced in a third-year materials selection course in the mechatronics systems engineering program at Western University. The overall project objective was to "reduce carbon emissions enough to avoid the worst consequences of climate change." Students worked in groups to carry out a 
sustainability assessment of a solution of their choice. In some cases, they chose solutions to other environmental issues. Solutions that they assessed included: clean meat, biodegradable plastics, geothermal power, wave power, microgrid power, nuclear power, conflict minerals in electronics, sustainable freight trains, delivery drones, sustainable clothing, afforestation, and Elon Musk's traffic tunnels. There were 17 teams of 3-5 students each.

\section{USING MICROSOFT TEAMS}

The teams collaborated online using Microsoft Teams [15]. Each Team was configured with "channels" corresponding to the stages of the sustainability assessment method: problem definition; stakeholder analysis; factfinding; synthesis; and conclusions and recommendations. Each channel was configured with a group chat conversation, a file document library, and a shared OneNote notebook. Setting up a team takes a couple of minutes. The instructor was a member of every team, and participated in team conversations.

\section{DEVELOPMENT OF GRADUATE ATTRIBUTES}

While the projects demonstrated the development of most if not all the CEAB graduate attributes, three attributes in particular were assessed: professionalism, impact of engineering on society and the environment, and life-long learning. Elements of the sustainability assessment project mapped very well to many of the Graduate Attribute indicators defined by the Faculty of Engineering at Western University, as shown in the tables below.

\subsection{Professionalism}

An understanding of the roles and responsibilities of the professional engineer in society, especially the primary role of protection of the public and the public interest [1].

\begin{tabular}{|l|l|}
\hline Western GA indicator & $\begin{array}{l}\text { Sustainability assessment } \\
\text { project }\end{array}$ \\
\hline $\begin{array}{l}\text { Recognizes role of } \\
\text { protection of public. }\end{array}$ & $\begin{array}{l}\text { Fact-finding under the } \\
\text { "society" category. } \\
\text { Impacts on environmental, } \\
\text { economic and social } \\
\text { sustainability. }\end{array}$ \\
\hline Stakeholder engagement. & $\begin{array}{l}\text { Identifying stakeholders } \\
\text { and their concerns. }\end{array}$ \\
\hline $\begin{array}{l}\text { Recognizes limitations of } \\
\text { regulations, codes and } \\
\text { technically based } \\
\text { analysis in a societal }\end{array}$ & $\begin{array}{l}\text { Fact-finding under the } \\
\text { "legislation and } \\
\text { regulations" category. }\end{array}$ \\
\hline
\end{tabular}

\begin{tabular}{|l|l|}
\hline context. & $\begin{array}{l}\text { Impact of legislation and } \\
\text { regulations on } \\
\text { sustainability. }\end{array}$ \\
\hline
\end{tabular}

\subsection{Impact of Engineering on Society and the Environment}

An ability to analyze social and environmental aspects of engineering activities. Such ability includes an understanding of the interactions that engineering has with the economic, social, health, safety, legal, and cultural aspects of society, the uncertainties in the prediction of such interactions; and the concepts of sustainable design and development and environmental stewardship [1].

\begin{tabular}{|l|l|}
\hline Western GA indicator & $\begin{array}{l}\text { Sustainability } \\
\text { assessment project }\end{array}$ \\
\hline $\begin{array}{l}\text { An understanding of the } \\
\text { interactions that } \\
\text { engineering has with the } \\
\text { economic, social, health, } \\
\text { safety, legal, and cultural } \\
\text { aspects of society, the } \\
\text { uncertainties in the } \\
\text { prediction of such } \\
\text { interactions. }\end{array}$ & $\begin{array}{l}\text { andironmental, economic } \\
\text { and social sustainability. }\end{array}$ \\
\hline $\begin{array}{l}\text { Concepts of sustainable } \\
\text { design and development } \\
\text { and environmental } \\
\text { stewardship. }\end{array}$ & Impacts on environmental \\
\hline
\end{tabular}

\subsection{Life-long Learning}

An ability to identify and to address their own educational needs in a changing world in ways sufficient to maintain their competence and to allow them to contribute to the advancement of knowledge [1].

\begin{tabular}{|c|c|}
\hline Western GA indicator & $\begin{array}{l}\text { Sustainability assessment } \\
\text { project }\end{array}$ \\
\hline $\begin{array}{l}\text { Motivation to identify } \\
\text { personal educational } \\
\text { needs in a changing } \\
\text { world. }\end{array}$ & $\begin{array}{l}\text { Fact-finding and } \\
\text { background research stage. }\end{array}$ \\
\hline $\begin{array}{l}\text { Ability to apply critical } \\
\text { analysis. }\end{array}$ & $\begin{array}{l}\text { Fact-finding and } \\
\text { background research stage, } \\
\text { when evaluating the quality } \\
\text { of information found from } \\
\text { different sources. }\end{array}$ \\
\hline $\begin{array}{l}\text { Organization of } \\
\text { knowledge. }\end{array}$ & $\begin{array}{l}\text { Fact-finding and } \\
\text { background research stage, } \\
\text { where facts and objective } \\
\text { knowledge are categorized. }\end{array}$ \\
\hline
\end{tabular}




\begin{tabular}{|l|l|}
\hline & $\begin{array}{l}\text { Evaluation and synthesis } \\
\text { phase, when information } \\
\text { and knowledge is } \\
\text { organized and linked to } \\
\text { support conclusions and } \\
\text { recommendations. }\end{array}$ \\
\hline Learn independently. & $\begin{array}{l}\text { Problem definition, } \\
\text { stakeholder analysis and } \\
\text { fact-finding phases, when } \\
\text { identifying and learning } \\
\text { about the issues and facts } \\
\text { related to a chosen topic. }\end{array}$ \\
\hline
\end{tabular}

\section{OBSERVATIONS AND REFLECTIONS}

\subsection{Microsoft Teams}

In general students found MS Teams easy to use, and used it extensively. The collaborative knowledge building process was visible as it happened, and the instructor could provide detailed guidance, feedback and suggestions as the project progressed. Students gathered and shared information from many different sources, and critically assessed the quality of the information. Using the framework, they synthesized the information to consider the positive and negative impacts of their chosen solution on manufactured, natural and human capitals. Finally, they documented the knowledge they had constructed in a written group report. In general, the written reports met or exceeded expectations in most if not all the graduate attribute indicators listed in the previous section.

The organization of the Teams into channels, each corresponding to a stage of the process, was a mixed success. Each channel has its own conversation and document library, and some teams preferred a single conversation thread and a single library. Having multiple channels caused confusion when organizing and searching for information. However, explicitly defining the stages provided useful guidance to student teams.

\subsection{Sustainability assessment and graduate indicators}

Some students expressed frustration that they were not able to invent a solution that would solve the problem of climate change, and that every existing solution had drawbacks as well as benefits. For many this was a first introduction to real-world wicked problems with no easy solution.

The resulting group reports met or exceeded the author's expectations in all the graduate attribute indicators being assessed. A systematic framework like the sustainability assessment method provides effective guidance and scaffolding for collaborative knowledge building, and for developing desired competencies.

\section{CONCLUSIONS AND NEXT STEPS}

This paper is a description of the tools and processes used in this course, and provides some preliminary observations, but it is not a formal research study. Ethics approval has been obtained to collect data from students regarding their perceptions and use of Microsoft Teams as a collaboration platform, and the effectiveness of the sustainability assessment project in developing the identified CEAB attributes. Data will be collected, and findings will be reported in a future paper.

\section{ACKNOWLEDGEMENTS}

The author wishes to acknowledge the support of Western's Teaching Fellowship, and the Teaching Support Centre, for sponsoring and assisting with this project.

\section{REFERENCES}

[1] 2017 Accreditation Criteria and Procedures. Canadian Engineering Accreditation Board, 2017.

[2] R. Buchanan, "Wicked problems in design thinking," Design issues, vol. 8, no. 2, pp. 5-21, 1992.

[3] P. Resta and T. Laferrière, "Technology in support of collaborative learning," Educational Psychology Review, vol. 19, no. 1, pp. 65-83, 2007.

[4] M. Scardamalia and C. Bereiter, "Knowledge building: Theory, pedagogy, and technology," The Cambridge Handbook of the Learning Sciences, pp. 97-115, 2006.

[5] G. Stahl, Group Cognition: Computer Support for Building Collaborative Knowledge. Cambridge, MA: MIT Press, 2006.

[6] L. Lipponen, K. Hakkarainen, and S. Paavola, "Practices and orientations of CSCL," What we know about CSCL, pp. 31-50, 2004.

[7] G. Stahl, "A model of collaborative knowledgebuilding," in Proceedings of the Fourth International Conference of the Learning Sciences, 2000, vol. 10, pp. 70-77.

[8] G. Singh, L. Hawkins, and G. Whymark, "An integrated model of collaborative knowledge building," Interdisciplinary Journal of Knowledge and Learning Objects, vol. 3, pp. 85-105, 2007.

[9] K. Stegmann, A. Weinberger, and F. Fischer, "Facilitating argumentative knowledge 
construction with computer-supported collaboration scripts," International Journal of Computer-Supported Collaborative Learning, vol. 2, no. 4, pp. 421-447, 2007.

[10] R. O. Buchal, "Web-based shared workspaces for collaborative learning," in Proceedings of the 2002 American Society for Engineering Education Annual Conference, 2002.

[11] R. Buchal and E. Songsore, "Collaborative Knowledge Building using Microsoft SharePoint," in Proc. 2018 Canadian Engineering Education Association Conf., 2018.

[12] M. Ashby, D. Ferrer, and J. Bruce, "Materials and Sustainable Development-a White Paper," Granta Design, Cambridge ( www. grantadesign. com/education/), 2013.

[13] M. Ashby and T. Vakhitova, "Active-Learning Took Kit - Sustainable Development," Granta Design, Cambridge ( www. grantadesign. com/education/), 2017.

[14] "What is CES Edupack." [Online]. Available: http://www.grantadesign.com/education/edupack/. [Accessed: 04-May-2018]

[15] “Microsoft Teams." [Online]. Available: https://products.office.com/en-CA/microsoftteams/. [Accessed: 21-Jan-2018] 